\title{
From sophisticates to sceptics: Direct and database marketing practice in UK SMEs
}

Received (in revised form): 22nd March, 2001

\begin{abstract}
Warwick Jones
is Associate Dean - Programmes and a former Head of the Marketing School at Bristol Business School. He has extensive international marketing management experience in food, healthcare and household products and has been a managing director of an SME. His consultancy and research interests are in strategic marketing planning processes, marketing orientation in public services, marketing in SMEs, relational marketing and higher education management. He has completed projects in the financial services, information systems, local government, higher education, police service and probation service sectors.
\end{abstract}

\section{Farooq Chudry}

is a senior lecturer in the Business School at the University of the West of England, His main teaching responsibilities include marketing research and direct marketing. He has over 20 years of experience in the IT and empirical research field. He is a member of a supervisory team that has a number of successfully completed PhDs to its credit. He is interested in researching consumer behaviour across different cultures, an area in which he has published several articles. In addition to teaching, he has done a considerable amount of consultancy work for both private and public sector clients.

\begin{abstract}
Despite the separate importance of direct marketing and small and medium-sized enterprises (SMEs) in the marketing and small business management literature few conceptual or empirical studies have attempted to integrate the two fields of study. The empirical study reported in this paper focuses on the usage, benefits and barriers to adoption of direct and database marketing in UK SMEs. The study identifies a range of roles for direct and database marketing, a range of factors influencing adoption and implementation, evidence of differences in attitudes and practice between firms and a number of implications for SMEs, suppliers and policy makers. As well as providing empirical evidence the results provide empirical support to and extensions of, the conceptualisation of direct marketing and the development and implementation of marketing strategy in SMEs.
\end{abstract}

Warwick Jones

Bristol Business School, University of the West of England, Frenchay Campus, Coldharbour Lane, Bristol BS16 1QY

Tel: +44(0)117 344 2692; Fax: 44(0)117 344 3903; e-mail:

Warwick.Jones@uwe.ac.uk

\section{INTRODUCTION}

The role of marketing in improving small and medium-sized enterprise (SME) performance is well documented and this makes the potential value of the fast developing field of direct and database marketing to SMEs of particular interest. It is widely accepted that SMEs have a major role to play in the economic development of Britain. In fact some see this sector as the lifeblood of the UK's economy with a significant workforce and turnover.

Therefore, reducing the number of SMEs that fail (up to 60 per cent cease trading, for a range of reasons, within four years of start-up according to UK VAT statistics) and increasing the number that are able to achieve their aim of making the transition into medium or large enterprises represents a continuing challenge for owners, managers, advisers, academics and public policy makers. 
Stone reports an enormous gap between the planned developments of world-class companies and the trailing edge, ie those companies which are just catching up with the use of technologies which have been around since the beginning of the 1990s. ${ }^{1}$ The implication is that SMEs could find themselves left even further behind in a battle for customers which is increasingly technology facilitated but is driven by informed and decisive management.

How direct marketing is, and should be utilised among SMEs and how suppliers of goods and services need to respond to support their needs are then important and under-researched areas.

There are various definitions of direct and database marketing. According to the US Direct Marketing Association, direct marketing is an element of marketing communications mix. The UK Institute of Direct Marketing considers it a strategic tool. Tapp, however, regards direct marketing as a complete marketing system, integrating analysis, planning, programme and control activities. ${ }^{2}$

Database marketing is regarded as management of customer data. ${ }^{3}$ This is consistent with Hartley and Starkey, ${ }^{4}$ who suggest database marketing is an interactive approach to customer contact management.

\section{Unique characteristics of SMEs}

It is well documented that SMEs have unique properties that differentiate them from large organisations and which result in marketing taking a different form.

These include: limited scope and scale of operations; ${ }^{5}$ management ownership and independence ${ }^{6}$ personalised and centralised management style $;^{7}$ lack of managerial skill and depth and personal lack and misuse of time; ${ }^{8}$ lack of financial resources; ${ }^{9}$ and strategic management as an adaptive rather than predictive process. ${ }^{10}$

\section{The nature of marketing in SMEs}

Carson identifies three broad types of constraints on the marketing of SMEs. They are: limited resources; lack of specialist expertise; limited impact on the marketplace. Carson also proposes four stages of marketing evolution, based on the business lifecycle concept, which are the norm for most SMEs. The four stages are: initial marketing activity; reactive selling; DIY marketing approach; integrated proactive marketing. ${ }^{11}$ The phases reflect the potential transition from an early product, then sales orientation, through tentative to professional marketing as possible barriers are reduced or removed. The characteristics of SMEs, and the probability that surveyed firms will be in a range of marketing phases provides an important context for the research.

\section{The role and impact of direct and database marketing in SMEs}

There is consensus among marketing authors about the economic advantages of direct and database marketing for small and medium-sized organisations. For example, Schupbach believes that loyal customers can be identified from customer databases and greater marketing effort can be expended on them for retention purposes. ${ }^{12}$ It is recognised that customers have more power today than ever before. Thus to create a point of difference in products and create loyalty, marketers must build customer relationships that add value to their brands. With the benefit of new technologies, companies must move away from traditional business approach and become customer focused. According to Stern and Barton, the marketing tools of 
today, especially database marketing, allow marketers effectively to put the 'custom' in the customer. ${ }^{13}$

Palmquist and Hart suggest that database marketing must support the overall strategy of an organisation since it allows more effective and efficient communications. ${ }^{14}$ Should an organisation choose this route, however, it can be costly and the impact felt company-wide. To be more effective, database marketing needs to support the company's overall strategy. Palmquist and Hart further suggest an integrated approach to this as disconnected programmes and initiatives are doomed to failure.

The encouraging signs are that a developing confidence and understanding of how to use information technology and improve business is accompanying the strong growth in IT investment by many of the SMEs. According to Wirszycs, SMEs are using IT and data-driven marketing to gain competitive advantage. ${ }^{15}$ A significant number of SME managers believe money spent on IT, training and support for direct marketing effort is well spent. SME managers are becoming more confident and competent in the buying and use of databases.

In exploring the potential benefits of direct and database marketing their impact on company performance is a significant issue. If the usage of direct and database marketing are associated with improved company performance then their adoption and appropriate use would contribute to increasing success of SMEs.

Greenley proposes a subjective approach to the measurement of company performance, which is adopted in this study. ${ }^{16}$ In this context, in this study respondents are asked to state how their company's return on investment, new product success and sales growth compare to that of their competitors.

\section{RESEARCH PURPOSE}

\section{Research aim}

The overall aim of the research is to investigate the usage and potential of direct marketing and related databases among SMEs.

\section{Objectives}

The objectives of the research are to:

- investigate the level of understanding of the concept of direct marketing

- determine who uses direct marketing

- investigate how direct marketing is used and what the perceived benefits are

- explore the usage of, and attitudes towards, customer databases

- identify barriers to the use of direct marketing and related databases in order to draw conclusions and make recommendations as to how they might be overcome.

\section{RESEARCH METHODOLOGY}

A hybrid methodology was adopted as follows:

\section{Qualitative research}

Sixteen individual depth interviews were conducted with SMEs in the South-west (9) and South-east (7) regions of the country in October/November 1997. The sample was structured so that a mixture of small and medium organisations were interviewed and within each of these subgroups there was a further division according to their use of direct marketing and databases.

\section{Quantitative data}

The quantitative phase of the research was in the form of a postal questionnaire, 


\begin{tabular}{|c|c|c|c|c|c|}
\hline & \multicolumn{5}{|c|}{ Size (No. of employees) } \\
\hline & $<\mathbf{1 0}$ & $10-24$ & 25-99 & $100-499$ & Total \\
\hline East & 961 & 611 & 350 & 297 & 2,219 \\
\hline SE pilot & 56 & 62 & 69 & 65 & 252 \\
\hline S. West & 1,057 & 576 & 442 & 144 & 2,219 \\
\hline \multirow[t]{2}{*}{ SW pilot } & 57 & 68 & 66 & 72 & 263 \\
\hline & 2,131 & 1,317 & 927 & 578 & 4,953 \\
\hline
\end{tabular}

which was mailed out to 5,000 SME organisations, divided equally between the South-west and South-east regions and split according to the size of the organisation. After the questionnaire had been devised it was subjected to a 'pre-pilot' test when some of the participants from the depth interviews completed it and highlighted any problems they experienced in doing so. The questionnaire was then finalised, the incentive described in a covering letter and the two combined with lists of names and addresses from a Dun and Bradstreet database held at the Centre for Research, Innovation and Industry at the University of the West of England (UWE).

The total sample of SMEs mailed, broken down by size (EU definition of SME) is shown in Table 1.

\section{Measuring instrument}

Questions have varying scales and continua: demographic questions are on dichotomous and categorical scales, attitudinal variables are measured on the Likert scale. ${ }^{17}$

\section{Reliability test}

Data were checked for internal consistency using Cronbach's Alpha test. ${ }^{18}$ Batteries of attitudinal questions were analysed. Values for this coefficient ranged between 0.785 to 0.833 for this data set, thus confirming acceptable level of reliability. ${ }^{19}$

\section{MAIN FINDINGS: QUANTITATIVE}

The profile of responding companies is shown in Table 2 (size of organisation by number of customers) and Table 3 (size of organisation by number of employees). Data were analysed using univariate, bivariate and multivariate techniques.

\section{Univariate analysis}

The variables on the questionnaire were aggregated to check for data transcription errors and distribution patterns.

\section{Direct marketing usage}

Fifty-nine per cent of all organisations reported using direct marketing (DM), while 79 per cent used databases.

Medium-sized organisations were more likely to be users of DM and databases than 'small' or 'micro' organisations.

Table 2: Size of organisation, number of customers

\begin{tabular}{ll}
\hline Number of customers & $\%$ of companies \\
\hline $10<$ & 2.5 \\
$10-99$ & 14 \\
$100-499$ & 23 \\
$500-999$ & 11 \\
$1,000-9,999$ & 32.5 \\
$10,000+$ & 17 \\
\hline
\end{tabular}

Table 3: Size of organisation, number of employees

\begin{tabular}{ll}
\hline Number of employees & $\%$ of companies \\
\hline$<10$ & 42 \\
$10-99$ & 44.5 \\
$100-499$ & 10 \\
$500+$ & 3.5 \\
\hline
\end{tabular}


Table 4

\begin{tabular}{lll}
\hline Uses of customer database & $\begin{array}{l}\text { \% of respondents } \\
\text { with databases } \\
\text { who do not use } \\
\text { direct marketing }\end{array}$ & $\begin{array}{l}\text { \% of respondents } \\
\text { with databases } \\
\text { and who use } \\
\text { direct marketing }\end{array}$ \\
\hline Targeting customers & 21 & 71 \\
Relationships with customers & 27 & 50 \\
Sales analysis & 32 & 40 \\
Triggering sales opportunity & 17 & 47 \\
Describing customers & 37 & 36 \\
Credit management & 23 & 28 \\
Response evaluation & 6 & 24 \\
Campaign evaluation & 2 & 21 \\
Individual buying patterns & 3 & 11 \\
Other & 9 & 9 \\
Base: all those with databases (442) & & \\
\hline
\end{tabular}

The reasons given for starting to use DM were evenly split between external and internal factors. Competitor activity and customer demand were seen to be the most important external factors with cost advantage and 'change in company focus' being the most important internal factors.

The primary purpose when using DM was reported as acquiring new customers, consequently the retention of existing customers took second place. The emphasis on attracting new customers was given as the main reason why DM was important. The greatest benefit of using DM was perceived as helping with targeting of customers and improving overall business performance.

The concentration of effort on new customers and targeting practices seemed, however, to result in a comparative neglect of the more strategic areas; response evaluation, campaign evaluation and modelling of purchasing patterns. On every dimension medium-sized companies were more positive about the benefits than small and micro companies.

\section{Database usage}

Almost half of those companies with a database reported using Microsoft products. Just under half of the respondents used more than one database.
The majority of companies had databases aged over five years.

Companies with a customer database did not always use it for DM purposes and conversely there were those that reported using DM without having a database.

The adoption of DM appears to be a powerful motivator for the development of a database. Only 3 per cent of firms who have adopted DM admit to having no database. Conversely 26 per cent of respondents have a database but do not report practising DM. Medium-size firms are more likely to practise direct marketing and have a database. Firms which have databases and practise direct marketing are more likely to use the database for targeting customers, developing customer relationships, triggering sales opportunities, response and campaign evaluation (see Table 4).

Within those organisations which did not have a database, over 50 per cent reported that it was not appropriate or not needed (either because 'paper records were sufficient' or because companies only dealt with small numbers of customers).

While there was a 'core' of these 'non-users' who would 'never' want a database, just over a quarter thought that they would acquire a database in the next five years. Among non-users of databases, a further barrier was that 61 per cent 
Table 5

\begin{tabular}{lll}
\hline $\begin{array}{l}\text { Organisation's performance } \\
\text { compared to competitor's }\end{array}$ & $\begin{array}{l}\text { \% of non-users of } \\
\text { direct marketing } \\
\text { rating much/slightly } \\
\text { better }\end{array}$ & $\begin{array}{l}\text { \% of users of } \\
\text { direct marketing } \\
\text { rating much/slightly } \\
\text { better }\end{array}$ \\
\hline Sales growth & 43 & 60 \\
Return on investment & 45 & 52 \\
New product success & 33 & 49 \\
Base: all respondents (557) & & \\
\hline
\end{tabular}

were not at all likely or not very likely to attend training courses to find out about DM and databases.

\section{Direct and database marketing strategy and performance}

When examining the type of relationship that a company had with its customers and linking this with its use of DM, just under a quarter of respondents reported using a database and DM to build a 'long distance' type of relationship. About three-quarters of companies reported that they tried to establish a 'one-to-one' type of relationship with customers based on personal interaction. This strategy was the most frequently chosen in all the main sectors investigated.

The effect of using DM and databases was indirectly assessed by examining self-reported company performance indicators. The users of DM and users of databases differed from non-users in that they rated their company performance better than their most important competitors on sales growth, return on investment and new product success (see Table 5).

\section{Bivariate Analysis}

The differentiators of the advocates and the sceptics among micro, small and medium-size firms

Questions relating to barriers to the introduction of databases into organisations and the important factors for organisations when choosing a customer database system were broken down by size of firm (micro, small and medium) using cross-tabulation (contingency) tables. A number of statistically significant differences (at 0.05 or less) were observed. These are reported in Table 6 .

It is evident from the cross-tabulations in Table 6 that there are statistically significant differences between the three different sizes of organisations when looking at a question which explores attitudes to databases and direct marketing. Micro, small and medium firms do differ in their attitudes to the usage of databases and direct marketing. They are likely to hold differing views on the extent to which databases help them focus on the needs of customers or the extent to which they perceive direct marketing as crucial to the operation of the business. The larger the firm, the more likely they are to be positive on these dimensions. Firms are also likely to respond differently in the extent to which they consider shortage of time, the absence of skills, the costs of external support or the absence of perceived benefits as significant issues. Conversely, the larger the firm the less likely they are to report these as significant issues.

When analysed in terms of numbers of customers, the three different sized firms are polarised even more 
Table 6: Breakdown by size of firm (micro, small and medium - in terms of number of employees)

\begin{tabular}{|c|c|c|c|}
\hline Attitudes to databases and direct marketing & $\chi^{2}$ & $\begin{array}{l}\text { Degrees of } \\
\text { freedom }\end{array}$ & $\begin{array}{l}\text { Level of } \\
\text { significance }\end{array}$ \\
\hline $\begin{array}{l}\text { a) Having a database has helped us focus on } \\
\text { the needs of the customers }\end{array}$ & 18.89 & 10 & 0.042 \\
\hline $\begin{array}{l}\text { b) I am so busy running the business I do not } \\
\text { have time to think about databases }\end{array}$ & 22.5 & 10 & 0.013 \\
\hline $\begin{array}{l}\text { c) Direct marketing is crucial to the operation of } \\
\text { the business }\end{array}$ & 27.2 & 10 & 0.002 \\
\hline $\begin{array}{l}\text { d) I cannot see any advantage in having a } \\
\text { database }\end{array}$ & 28.49 & 10 & 0.017 \\
\hline $\begin{array}{l}\text { e) We do not have the direct marketing skills } \\
\text { inside the company to operate a database }\end{array}$ & 19.37 & 10 & 0.036 \\
\hline $\begin{array}{l}\text { f) Using external direct marketing/database } \\
\text { companies would cost a fortune }\end{array}$ & 19.91 & 10 & 0.041 \\
\hline
\end{tabular}

$N=557$

Table 7: Breakdown by size of firm (number of customers)

\begin{tabular}{llll}
\hline Question & $\chi^{2}$ & $\begin{array}{l}\text { Degrees of } \\
\text { freedom }\end{array}$ & $\begin{array}{l}\text { Level of } \\
\text { significance }\end{array}$ \\
\hline $\begin{array}{l}\text { a) Having a database has helped us focus on } \\
\text { the needs of the customers }\end{array}$ & 57.11 & 15 & 0.000 \\
$\begin{array}{l}\text { b) I am so busy running the business I do not } \\
\quad \text { think about databases }\end{array}$ & 43.62 & 15 & 0.000 \\
$\begin{array}{l}\text { c) Direct marketing is crucial to the operation of } \\
\text { the business }\end{array}$ & 67.77 & 15 & 0.000 \\
$\begin{array}{l}\text { d) I cannot see any advantage in having a } \\
\text { database }\end{array}$ & 86.58 & 15 & 0.000 \\
$\begin{array}{l}\text { e) We do not have the direct marketing skills } \\
\text { inside the company to operate a database }\end{array}$ & 33.95 & 15 & 0.003 \\
\hline
\end{tabular}

$\mathrm{N}=557$

significantly (Table 7). Medium-sized firms have consistently reported positively on the benefits offered by direct and database marketing at both strategic and tactical levels compared to micro and small-sized companies. It is also confirmed that the more customers the firm has the more likely it is to agree that having a database has helped it focus on the needs of customers and that DM is crucial to the operation of the business. Again, firms with large numbers of customers are also less likely to report being busy, the absence of benefits, the lack of skills, or the cost of support from external companies as reasons for not operating a database.

\section{Dimensionality analysis}

\section{The importance of the numbers of customers}

The factor analysis technique was used to reduce large sets of attitudinal questions to more meaningful (and manageable) numbers of underlying constructs. Briggs and Cheek suggest that factors should be conceptually meaningful and empirically useful. ${ }^{20}$ The factors that emerged in this study, though subjectively labelled, are consistent with this assertion.

Each battery of questions was investigated in turn. The factor analysis process produced both initial (principal component) and rotated factors. Varimax rotation was favoured since it allowed 
Table 8: The sceptics: Factor analysis A

\begin{tabular}{|c|c|c|c|}
\hline & $\begin{array}{l}\text { Factor } 1 \\
\text { 'Don't need } \\
\text { one' } \\
23 \% \text { variance }\end{array}$ & $\begin{array}{l}\text { Factor } 2 \\
\text { 'Lacking } \\
\text { resources' } \\
22 \% \text { variance }\end{array}$ & $\begin{array}{l}\text { Factor } 3 \\
\text { 'Lack of } \\
\text { competence' } \\
19 \% \text { variance }\end{array}$ \\
\hline Paper records are sufficient & 0.720 & 0.285 & 0.001 \\
\hline We do not see a need for database & 0.809 & 0.317 & -0.15 \\
\hline There is lack of long-term planning & -0.003 & 0.005 & 0.803 \\
\hline We are customer orientated & 0.543 & -0.002 & 0.425 \\
\hline $\begin{array}{l}\text { The cost of investment and operations is } \\
\text { too high }\end{array}$ & 0.169 & 0.814 & 0.103 \\
\hline $\begin{array}{l}\text { The time needed to enter back data is too } \\
\text { high }\end{array}$ & -0.006 & 0.884 & 0.191 \\
\hline $\begin{array}{l}\text { Problems with compatibility of existing } \\
\text { systems }\end{array}$ & 0.223 & 0.550 & 0.341 \\
\hline Lack computer knowledge and skills & 0.003 & 0.325 & 0.689 \\
\hline $\begin{array}{l}\text { Too much dependence on external } \\
\text { expertise }\end{array}$ & 0.292 & 0.401 & 0.567 \\
\hline We only have a small number of customers & 0.785 & -0.180 & 0.231 \\
\hline
\end{tabular}

$\mathrm{N}=557$

the factors to remain uncorrelated with each other thus yielding 'clear' factors. ${ }^{21}$

This clearly establishes a link between the size of firm and its attitude towards database and DM but, more importantly, indicates that the number of customers rather than the number of employees is the most important factor.

The sceptics: three significant customer groupings emerged among those with negative attitudes to databases. Those reporting that they do not need a database emphasise small numbers of customers and the consequent adequacy of paper records as the main reason. Micro and small firms who say they do not need a database, however, are also likely to report that they feel that the cost of investment and operations would be too high, as would the cost of entering back data (see Tables 8-11). Those reporting lack of resources point to the cost of investment and operating costs and the time needed to enter back data as the major inhibitors. Small and medium-sized firms nonetheless tend to report that they are customer orientated and often indicate that they have small numbers of customers. This could provide a rationale for not adopting databases. Micro firms reporting a lack of resources are significantly less likely to report being customer-oriented. Those claiming lack of competence report a lack of long-term planning, the lack of computer knowledge and skills and too much dependence on external experience as the major factors. Micro firms who report lacking resources as an important barrier to acquisition of a database strongly disagree, interestingly, that there is also a lack of long-term planning. Whereas small and medium-sized firms who highlight resourcing issues are more likely to point to a lack of long-term planning.

There is an important group of micro firms which report strong customer orientation and small customer numbers. Their lack of enthusiasm for databases may be entirely rational at this stage of their development.

Of those companies reporting cost as a significant factor in their negative attitude to database and direct marketing the capital cost of the hardware and software, operating costs, reliability, ease of use, reputation of the supplying company are all important factors. Again there are important differences between the 
Table 9: The sceptics: Factor analysis A - micro

\begin{tabular}{|c|c|c|c|c|}
\hline & $\begin{array}{l}\text { Factor } 1 \\
\text { 'Don't need } \\
\text { one' }\end{array}$ & $\begin{array}{l}\text { Factor } 2 \\
\text { 'Lacking } \\
\text { resources' }\end{array}$ & $\begin{array}{l}\text { Factor } 3 \\
\text { 'Lack of } \\
\text { competence' }\end{array}$ & $\begin{array}{l}\text { Factor } 4 \\
\text { 'Few } \\
\text { customers' }\end{array}$ \\
\hline $\begin{array}{l}\text { Paper records are sufficient } \\
\text { We do not see a need for } \\
\text { database }\end{array}$ & $\begin{array}{l}0.111 \\
0.171\end{array}$ & $\begin{array}{l}0.752 \\
0.656\end{array}$ & $\begin{array}{r}0.174 \\
-0.159\end{array}$ & $\begin{array}{l}0.009 \\
0.497\end{array}$ \\
\hline $\begin{array}{l}\text { There is lack of long-term } \\
\text { planning }\end{array}$ & 0.172 & -0.719 & 0.321 & 0.008 \\
\hline $\begin{array}{l}\text { We are customer orientated } \\
\text { The cost of investment and } \\
\text { operations is too high }\end{array}$ & $\begin{array}{l}0.225 \\
0.621\end{array}$ & $\begin{array}{r}-0.007 \\
0.403\end{array}$ & $\begin{array}{l}0.008 \\
0.304\end{array}$ & $\begin{array}{r}0.846 \\
-0.148\end{array}$ \\
\hline $\begin{array}{l}\text { The time needed to enter back } \\
\text { data is too high }\end{array}$ & 0.883 & 0.006 & 0.230 & -0.597 \\
\hline $\begin{array}{l}\text { Problems with compatibility of } \\
\text { existing systems }\end{array}$ & 0.745 & -0.170 & 0.0038 & 0.309 \\
\hline $\begin{array}{l}\text { Lack computer knowledge and } \\
\text { skills }\end{array}$ & 0.188 & -0.190 & 0.820 & 0.126 \\
\hline $\begin{array}{l}\text { Too much dependence on external } \\
\text { expertise }\end{array}$ & 0.129 & 0.0089 & 0.850 & 0.006 \\
\hline $\begin{array}{l}\text { We only have a small number of } \\
\text { customers }\end{array}$ & -0.203 & 0.390 & 0.208 & 0.654 \\
\hline
\end{tabular}

$\mathrm{N}=557$

Table 10: Factor analysis $A-$ small

\begin{tabular}{lccc}
\hline & $\begin{array}{c}\text { Factor 1 } \\
\text { 'Don't need } \\
\text { one' }\end{array}$ & $\begin{array}{l}\text { Factor 2 } \\
\text { 'Lacking } \\
\text { resources' }\end{array}$ & $\begin{array}{c}\text { Factor 3 } \\
\text { 'Lacking } \\
\text { competence' }\end{array}$ \\
\hline $\begin{array}{l}\text { Paper records are sufficient } \\
\text { We do not see a need for database }\end{array}$ & 0.003 & $\mathbf{0 . 6 2 9}$ & 0.443 \\
$\begin{array}{l}\text { There is lack of long-term planning } \\
\text { We are customer orientated }\end{array}$ & 0.320 & $\mathbf{0 . 7 6 2}$ & -0.007 \\
$\begin{array}{l}\text { The cost of investment and operations is } \\
\text { too high }\end{array}$ & 0.205 & 0.184 & $\mathbf{0 . 7 7 3}$ \\
$\begin{array}{l}\text { The time needed to enter back data is too } \\
\text { high }\end{array}$ & $\mathbf{0 . 9 1 4}$ & $\mathbf{0 . 7 8 0}$ & -0.003 \\
$\begin{array}{l}\text { Problems with compatibility of existing } \\
\text { systems }\end{array}$ & $\mathbf{0 . 6 0 4}$ & -0.001 & 0.122 \\
$\begin{array}{l}\text { Lack computer knowledge and skills } \\
\text { Too much dependence on external }\end{array}$ & 0.208 & 0.439 & 0.218 \\
$\begin{array}{l}\text { expertise } \\
\text { We only have a small number of customers }\end{array}$ & -0.620 & 0.009 & 0.211 \\
\hline
\end{tabular}

$\mathrm{N}=557$

companies. Small firms emphasise capital costs and ease of use factors. Micro firms seem to polarise into two groups. One is concerned with cost and ease of use factors but has little concern about compatibility or use for DM purposes. These may be first-time purchasers who appear to be particularly concerned with the reputation of any supplying company. A second group of micro firms are particularly concerned with the direct marketing application of the database and compatibility with existing systems. These could be existing users or informed potential users who are more concerned with value than cost. Medium-size firms also break down into two groups: the first does not have any particular concerns about DM application of the database but is highly concerned 
Table 11: Factor analysis $A-$ medium

\begin{tabular}{|c|c|c|c|}
\hline & $\begin{array}{l}\text { Factor } 1 \\
\text { 'Don't need } \\
\text { one' }\end{array}$ & $\begin{array}{l}\text { Factor } 2 \\
\text { 'Lacking } \\
\text { resources' }\end{array}$ & $\begin{array}{l}\text { Factor } 3 \\
\text { 'Lacking } \\
\text { competence' }\end{array}$ \\
\hline Paper records are sufficient & 0.977 & 0.000 & 0.203 \\
\hline We do not see a need for database & 0.709 & 0.566 & 0.318 \\
\hline There is lack of long-term planning & 0.499 & 0.786 & 0.234 \\
\hline We are customer orientated & 0.009 & 0.784 & 0.585 \\
\hline $\begin{array}{l}\text { The cost of investment and operations is } \\
\text { too high }\end{array}$ & 0.485 & 0.240 & 0.766 \\
\hline $\begin{array}{l}\text { The time needed to enter back data is too } \\
\text { high }\end{array}$ & 0.335 & -0.819 & 0.313 \\
\hline $\begin{array}{l}\text { Problems with compatibility of existing } \\
\text { systems }\end{array}$ & 0.930 & -0.219 & -0.186 \\
\hline $\begin{array}{l}\text { Lack computer knowledge and skills } \\
\text { Too much dependence on external } \\
\text { expertise }\end{array}$ & $\begin{array}{r}-0.287 \\
0.009\end{array}$ & $\begin{array}{l}0.004 \\
\mathbf{0 . 7 8 6}\end{array}$ & $\begin{array}{l}0.965 \\
0.585\end{array}$ \\
\hline We only have a small number of customers & 0.782 & 0.407 & 0.208 \\
\hline
\end{tabular}

$\mathrm{N}=557$

Table 12: Factor analysis $B$

\begin{tabular}{|c|c|c|c|c|c|c|}
\hline & $\begin{array}{l}\text { All } \\
\text { firms }\end{array}$ & Micro & Micro & Small & Medium & Medium \\
\hline & $\begin{array}{l}\text { Factor } 1 \\
\text { 'Cost' } \\
\mathbf{5 0 \%} \\
\text { variance }\end{array}$ & Factor 1 & Factor 2 & Factor 1 & Factor 1 & Factor 2 \\
\hline $\begin{array}{l}\text { Compatibility with existing } \\
\text { systems }\end{array}$ & 0.591 & 0.009 & 0.708 & 0.702 & 0.705 & 0.001 \\
\hline $\begin{array}{l}\text { Capital costs of hardware and } \\
\text { software }\end{array}$ & 0.776 & 0.548 & 0.503 & 0.829 & 0.858 & 0.138 \\
\hline Operating costs & 0.745 & 0.625 & 0.424 & 0.753 & 0.735 & 0.328 \\
\hline $\begin{array}{l}\text { Would be able to use it for DM } \\
\text { purposes }\end{array}$ & 0.508 & -0.023 & 0.729 & 0.664 & -0.009 & 0.838 \\
\hline Reliability & 0.818 & 0.604 & 0.479 & 0.856 & 0.754 & 0.450 \\
\hline Recommendation & 0.659 & 0.684 & 0.001 & 0.699 & 0.439 & 0.532 \\
\hline Would be easy to use & 0.790 & 0.783 & 0.189 & 0.826 & 0.449 & 0.678 \\
\hline Reputation of company & 0.708 & 0.781 & -0.004 & 0.753 & 0.509 & 0.551 \\
\hline
\end{tabular}

$\mathrm{N}=557$

with compatibility with existing systems costs and reliability; the second is not at all concerned with existing system compatibility but is concerned with the DM application of the database (see Table 12).

The advocates The initial factor analysis phase was followed up by conducting the same analysis for different subgroups in the data (see Table 13). Respondents who were self-declared advocates of DM were significantly more likely to report that having a database has helped them focus on the needs of the customer, that DM is crucial to the operation of the company and that they could see an advantage in having a database. This reconfirms the probable linkage between the development of a clear direct marketing strategy, the implementation of a related database and consequent business benefits. Within this group however there were important differences between micro and small firms and 
Table 13: Factor analysis $C$

\begin{tabular}{|c|c|c|c|c|c|c|c|c|}
\hline & All firms & All firms & Micro & Micro & Small & Small & Medium & Medium \\
\hline & $\begin{array}{l}\text { Factor } 1 \\
\text { Advocate } \\
\text { of DM } \\
31 \% \\
\text { variance }\end{array}$ & $\begin{array}{l}\text { Factor } 2 \\
\text { The } \\
\text { sceptic } \\
30 \% \\
\text { variance }\end{array}$ & Factor 1 & Factor 2 & Factor 1 & Factor 2 & Factor 1 & Factor 2 \\
\hline $\begin{array}{l}\text { Having a database has } \\
\text { helped us focus on the } \\
\text { needs of the customer }\end{array}$ & 0.786 & -0.002 & 0.790 & 0.001 & 0.787 & -0.101 & -0.705 & 0.110 \\
\hline $\begin{array}{l}\text { I am too busy running } \\
\text { the business I do not } \\
\text { have the time to think } \\
\text { about databases }\end{array}$ & -0.214 & 0.735 & -0.114 & 0.746 & -0.112 & 0.784 & 0.761 & 0.006 \\
\hline $\begin{array}{l}\text { Direct marketing is crucial } \\
\text { to the operation of the } \\
\text { company }\end{array}$ & 0.835 & -0.004 & 0.781 & 0.003 & 0.863 & -0.007 & -0.471 & -0.543 \\
\hline $\begin{array}{l}\text { I cannot see any } \\
\text { advantage in having a } \\
\text { database }\end{array}$ & -0.614 & 0.450 & -0.698 & 0.404 & -0.497 & 0.531 & 0.279 & 0.816 \\
\hline $\begin{array}{l}\text { We do not have the } \\
\text { direct marketing skills } \\
\text { inside the company to } \\
\text { operate a database }\end{array}$ & -0.221 & 0.767 & -0.262 & 0.778 & -0.111 & 0.783 & 0.604 & 0.210 \\
\hline $\begin{array}{l}\text { Using external direct } \\
\text { marketing/database } \\
\text { companies would cost a } \\
\text { fortune }\end{array}$ & 0.284 & 0.672 & 0.150 & 0.701 & 0.460 & 0.523 & -0.270 & 0.668 \\
\hline
\end{tabular}

medium-size firms. Micro and small firms tended to agree that databases helped them focus on the needs of the customer and that DM was crucial to the operation of the business. Medium-sized firms, however, who were advocates of DM, did not appear to attribute their focus on the needs of the customer to the use of databases. Nor was DM, despite their support for it, seen as crucial to the operation of the company.

\section{DISCUSSION}

The main aim of the discussion that follows is descriptive rather than critical. The evidence from this study suggests that DM is well established as 'direct mail', but there is clearly scope for further development in other media.
It is clear that direct and database marketing are not always associated with each other. In this study although virtually all direct marketers claimed to use databases, around a quarter of SMEs claimed to use a customer database but not to practise DM. This certainly provides support for those seeking to maintain separate definitions of DM and database marketing.

Almost all organisations employing DM used it for the acquisition of new customers or for targeting, with few using it for customer retention. Fewer still reported using it for acquiring customer information, quantifying the effect of campaigns or improving the management of customer contact. Thus, although it appears many SMEs understand the potential benefits of DM, 


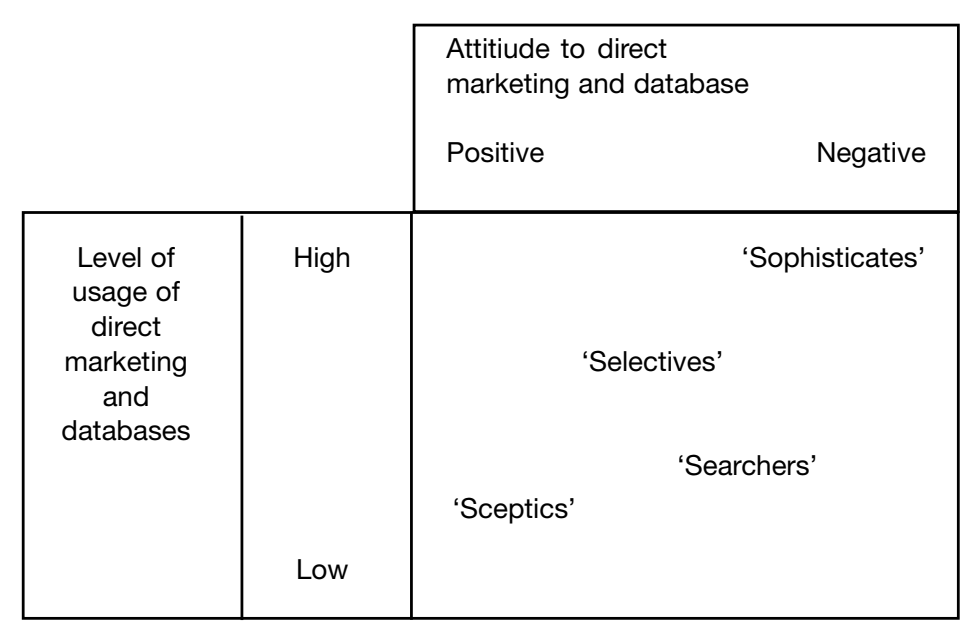

Figure 1: The direct and database marketing adoption matrix

many may be some way short of unlocking its true potential.

Most firms, however, reported marketing strategies which were focused on building one-to-one relationships with customers based on personal interaction, with a much smaller group reporting using a database and direct marketing to build a long-distance type of relationship with customers.

The extent of use of DM and databases appear to be industry-specific; for example, the motor trade, publishing and printing and, to a lesser extent, leisure and travel showing greater sophistication. The financial services sector lagged behind these in terms of current use of DM. The age and number of databases in use within client companies may, however, act as an impediment to the development of more sophisticated uses as their current systems may be unable to cope with such demands.

The differential usage of direct marketing and databases among SMEs and their increased usage as firm size (numbers of employees) increases lends some support to Carson's four stages of marketing evolution. The stages assume the progressive acquisition of a market orientation as marketing knowledge and responsiveness to customer and competitor demands increases and the constraints of limited resources, lack of specialist expertise and limited impact on the marketplace are overcome. The findings of this study indicate, however, that it would be wrong to assume that an overall progression from initial marketing activity to integrated proactive marketing should be mirrored by progression towards the acquisition of a sophisticated direct marketing system or an integrated database among all SMEs. Rather the findings suggest that there may be some significant groupings of SMEs, differentiated by their attitude to DM and databases and the level of sophistication of their use of them. Although the findings do not directly define and measure these potential groups there is sufficient evidence to suggest four possible SME groups summarised in the matrix in Figure 1. The matrix defines a group of 'Sophisticates', who have the most positive attitude to DM and databases and are the most sophisticated users of 
them. These are to be medium-sized firms who have identified a major, possibly central, role for DM and databases in their marketing strategy and who perceive them to be delivering major performance benefits. They are likely to have moved beyond usage for customer targeting into integrated customer acquisition and retention programmes emphasising the capture and analysis of customer information, strategy and campaign development and campaign evaluation. The 'Selectives ' are more sanguine about the benefits or DM and databases but may nonetheless be fairly sophisticated users. Direct and database marketing may not be central to their marketing strategy either for product/customer reasons or because careful cost/benefit analysis has not convinced them that more extended usage is appropriate. They are nonetheless informed and interested in further development. The 'Searchers' are those trying to gain an understanding of direct and database marketing and to define a role for them in their businesses. They may be experimenting with different approaches, and may have made some mistakes. They have probably overcome some of the barriers to implementation and in particular it is possible that management attitudes and skills are no longer insurmountable barriers. They may though be more positive about their potential than is appropriate and may be more disillusioned by failure. They would be expected to move to a 'Sophisticate' or 'Selective' position over time. 'The 'Sceptics' are likely to have little or no usage of direct and database marketing and are the most negative about their potential value. Management, resource and skills barriers may still be significant and their small numbers of customers may limit the attractiveness of investment in new media or systems.

\section{IMPLICATIONS}

\section{SME companies, suppliers and policy makers}

All those interested in improving the performance of SMEs should note the role of DM and databases in the self-reported improved performance of these firms. The promotion of direct and database marketing to them would be worthwhile, as would the development of programmes to help overcome the barriers to adoption. The strongest appeals which could be used to stimulate the use of DM would be: acquires new customers, targets customers, achieves sales growth, helps retain existing customers, promotes new product success and improves profitability. The identification of the four SME subgroups ('Sophisticates', 'Selectors', 'Searchers' and 'Sceptics') suggests potential value in the development of differentiated solutions and communications.

SME companies who are current users of DM and databases need to consider if they are getting the best out of their systems and utilising their resources to their fullest extent. For example, rather than just using the database to target new customers, they could use it to segment their customer base on specific criteria to maximise profitability. They could examine the possibilities of using more diverse media, rather than direct mail and they could introduce procedures to evaluate campaigns.

As a substantial proportion of the databases within SME companies are comparatively old, there is an opportunity for vendors of database systems to provide a service to update those systems and also to develop customised products to serve the needs of particular industry sectors.

\section{Future research}

Future research could usefully concentrate on the validation of the definition and nature of the SME 
subgroups reported here and exploration within each of the practices that enable them to develop the appropriate usage of direct and database marketing within an SME environment.

\section{References}

1 Stone, M., Byrne, S., Knight, G., Loader, G. and Thompson, H. (1998). 'The future of relationship marketing: Towards transparent marketing?', The Journal of Database Marketing, Vol. 6, No. 1, pp. $11-23$.

2 Tapp, A. J. (1998) 'Principles of direct and database marketing', Prentice Hall, pp. 8-11.

3 Fletcher, K., Wheeler, C. and Wright, J. (1995) 'The role and status of UK database marketing', Quarterly Review of Marketing, Autumn, pp. 7-14.

4 Hartley, R. A. and Starkey, M. W. (eds) (1996) 'The management of sales and customer relations', International Thompson Business Press, p. 158.

5 Schollhammer, H. and Kurilof, A. (1979) 'Entrepreneurship and small business management', John Wiley \& Sons, p. 179.

6 Ibid.

7 Ibid.

8 Broom, H. H., Longenecker, J. and Moore, C. W. (1993) 'Small business management', sixth edition, South Western Publishing Co., p. 585.

9 Hodgetts, R. M. (1992) 'Effective small business management', Academic Press, pp. 33-34.
10 Faulkner, D. and Johnson, G. (1992) 'The challenge of strategic management', Kogan Page, London.

11 Carson, D. J. (1985) 'The evolution of marketing in small firms'. European Journal of Marketing, Vol. 19, No. 5, pp. 23-33

12 Schupbach, A. (1997) Direct Marketing, Vol. 60, Iss. 8, pp. 28-29.

13 Stern, S. and Barton, D. (1997) 'Strategy and leadership', Vol. 25, Iss. 3, pp. 46-50.

14 Palmquist, J. and Hart, P. (1996) Marketing News, Vol. 30, Iss. 16, pp. 10.

15 Wirszycs, R. (1998) Management Today, Iss. 25, pp. 92-94.

16 Greenley, G. E. (1995) 'Forms of market orientation in UK companies', Journal of Management Studies, Vol. 32, No. 1, January.

17 Likert, R. (1932a) 'The method of constructing an attitude scale,' in Fishbein, M. (1967) (ed.) 'Readings in attitude theory and measurement', John Wiley, New York, NY, pp. 90-5

18 Campbell, D. T. and Fiske, D. W. (1959) 'Convergent and discriminant validity by multitrait-multimethod matrix', Psychological Bulletin, Vol. 56, pp. 81-105.

19 Carmines, E. G. and Zeller, R. A. 'Reliability and validity assessment', Sage Publications, CA.

20 Briggs, S.R. and Cheek, J. M. (1986) 'The role of factor analysis in development and evaluation of personality scales', Journal of Personality, Vol. 54, pp. 106-148.

21 Nunnally, J. (1967) 'Psychometric theory', McGraw-Hill, New York. 